\title{
TRANSFORMATION OF THE STRATEGY OF STATE ECONOMIC POLICY IN MODERN CONDITIONS
}

\author{
laroslav Petrunenko', Oleg Podtserkovnyi
}

\begin{abstract}
Complex and contradictory processes of modern social transformations and the need to overcome the crisis in the economy require the appropriate influence of the state and a clear system of socio-economic management through the formation and implementation of effective state economic policy. The main elements of economic policy are financial and credit, budgetary, scientific and technical, structural, social, investment, agricultural, regional, foreign economic policy. The implementation of state economic policy is considered in terms of the relationship between social problems and the state. Therefore, the purpose of the article is to study the essence, tools and methods of state economic policy in modern conditions. It is also necessary to identify the main risks and features of further development of state economic policy of individual states in a global imbalance and crisis. The theoretical part is devoted to the study of the essence of state economic policy, theoretical and practical aspects of its organization in the state, as well as tools that can be used by the state. The resulting part is devoted to the consideration of the situation, in which the world economy has found itself in 2020 in the conditions of the economic COVID-19 crisis. General forecasts have not provided to individual states because it has been impossible to predict the end of the pandemic and the return of the world to normal life. However, it is clear that the world economy has undergone irreversible processes that will synergistically affect different states in different ways. The crisis has hit a significant number of industries, including tourism, logistics, hotel business, the crisis has been felt in world markets: oil prices have collapsed, as well as the stock markets. Undoubtedly, there are areas with a rapid growth, especially the pharmaceutical industry and retail, online delivery services, IT entertainment and communications industry, information marketing business and education and training services. It is likely that the indicators of economic development in the states by the end of the year will be better than the results of the first half of the year. The basic forecast of economic world development assumes a sharp growth of the economy after a short recession after quarantine. The financial capabilities of the EU states vary considerably, but each state must pursue counter-cyclical policies aimed at stabilizing its own economy. The answer to the question of what kind of crisis response policy they can afford depends on the fiscal policy of the states before the crisis. In economically developed states, where emergency measures have been introduced, governments and central banks issue trillions of dollars in government spending, social support of citizens, and interest-free business loans to limit the economic damage of quarantine. At the same time, in Latin America and Southeast Asia, total quarantine is impossible in multi-million cities. Such states have a triple effect of suffering from the virus, the environment and poverty. States dependent on the export of natural resources and raw materials, when faced with the crisis, are forced to sell them for nothing, so they will suffer great losses. More than 150 states have set up anti-crisis headquarters and are taking anti-crisis measures. The authors have also tried to predict how largescale the global economic crisis will be for Ukraine, what consequences await it, and what measures need to be taken to overcome it.
\end{abstract}

Key words: economic policy, COVID-19 crisis, consequences of crisis, state mechanism, anti-crisis headquarters, anti-crisis measures, Ukrainian policy, forecast scenario, forecast risks.

JEL Classification: E01, E60, H77, 011

\footnotetext{
Corresponding author:

${ }^{1}$ National University «Odesa Law Academy», Ukraine.

E-mail: petrunenko@email.ua

ORCID: https://orcid.org/0000-0002-1186-730X

${ }^{2}$ National University «Odesa Law Academy», Ukraine.

E-mail: opp@ukr.net

ORCID: https://orcid.org/0000-0003-1095-3481
} 


\section{Introduction}

Complex and contradictory processes of modern social transformations and the need to overcome the crisis in the economy require the appropriate influence of the state and a clear system of socioeconomic management through the formation and implementation of effective state economic policy.

Such researches have become especially relevant in 2020 , when the state's ability to protect and care for its citizens has become a significant guiding factor. The main elements of adaptive economic policy, which come to the fore, are, on the one hand, the possibility of increasing the influence of public administration, and on the other hand, increasing responsibility for the efficiency of socio-economic life, rational use of internal potential and use of untapped sources of development at the level of regions and smaller territorial units.

During all the decades of state-building processes, a significant number of scientists and researchers have dealt with the issues of theoretical and methodological foundations of the implementation of state economic policy. From the point of view of methodological approaches, the comparative legal approach is relevant, which makes it possible to properly justify ways to improve economic policy, taking into account the positive experience of developed states and to avoid mistakes. The purpose of state policy is to create conditions for dynamic, balanced development of the state and its regions, ensuring their social and economic unity, improving living standards, compliance with state-guaranteed social standards for every citizen regardless of his or her place of residence.

The process of integration into the European Union can be attractive in terms of gaining experience of collective interaction, creating a mechanism for forming and strengthening the norms of democracy, revising the rule of law, human freedoms and rights, and accelerating economic development that will positively influence on the living standards (Soloviov, 2017).

To master the pace of integration processes, it is necessary to distinguish between the peculiarities of foreign economic activity and priority areas for foreign economic activity. For example, for Ukraine in 2017, seven priority areas of cooperation with the EU were identified, such as energy, trade and investment, justice and domestic affairs, approximation of the Ukrainian legislation to the EU legislation, environmental protection, transport, and cross-border cooperation, cooperation in science, technology and space (Kulysh, 2019). In recent years, this trend has not changed, but rather deepened.

\section{Methodology of research}

State economic policy is based on the theoretical and methodological principles of economic theory, on knowledge of objective economic laws, needs, interests and goals of various economic entities. The main elements of economic policy are financial and credit, budgetary, scientific and technical, structural, social, investment, agricultural, regional, foreign economic policy. The implementation of state economic policy is considered in terms of the relationship between social problems and the state.

The algorithm for implementing state policy can be divided into certain stages. At the first stage of economic policy implementation the state determines the most acute problems of the state, at the second stage, it develops a strategy and plan for their solution, as well as legislates (legitimizes) policy, at the third stage, it takes measures to solve these problems, and at the final stage, the state evaluates the results and determines the direction of future action.

State economic policy can be seen as a mechanism for using regulatory instruments to achieve national interests. This policy consists of two main aspects: theoretical and practical.

The theoretical aspect of state economic policy involves a systematic scientific study of methods, actions and measures aimed at ensuring and supporting the most effective development of the national economy, as well as the formation of economic thinking.

The practical aspect of state economic policy is associated with the development of a system of specific measures for state regulation of the economy, which, in turn, involves the disclosure of the essence of the mechanism of formation and implementation of economic policy.

State economic policy is a set of forms, methods, principles and tools, by which the state influences the activities of economic entities and market conditions in order to create appropriate conditions for the functioning of the market and solve socio-economic problems of society.

The implementation of state economic policy is a continuous, dynamic process of achieving the set goals, in which various public authorities and civil society institutions participate. Implementation begins immediately after the approval and legitimation of state economic policy or a separate program and is the main activity of public authorities.

The formation and implementation of state economic policy is carried out in four stages (this process is also called the political cycle):

Stage 1 - definition of social problems and policy goals (policy initiation).

Stage 2 - development and legitimation of state economic policy (policy formation).

Stage 3 - implementation and monitoring of state economic policy (policy implementation).

Stage 4 - evaluation and regulation of state economic policy (policy evaluation) (Belyaev, 2003).

The main elements of the mechanism of economic policy are characterized by such terms as subject, object, goals, methods and means. 
As a rule, under the subjects of economic policy a state only is meant. However, this understanding is quite simplistic. In fact, the subjects of economic policy are both carriers and representatives of economic interests. These include various types of associations that express the interests of certain strata and groups of the population. These are, first of all, trade unions and associations of entrepreneurs.

Public authorities, including regional and local institutional structures, use their power to reconcile the economic interests of different groups of producers and the population of the state, directing their work to achieve a common goal (Umantsiv, 2015).

Objects of state economic policy are areas, industries, regions, as well as phenomena, situations and conditions of economic life of the state, where certain problems have arisen or may arise that are not solved automatically, as required by the normal functioning of the economy and social stability.

Objects of state economic policy are: economic cycle; structure of the economy; conditions of investment activity; scientific and technological progress and innovation processes; money circulation and inflation; balance of payments; social problems (employment, income, training and retraining, social protection, etc.); conditions of competition; environment (environmental problems); regions (Didkivs'ka, Holovko, 2000).

The methodology of economic policy of the state should be based on certain approaches and principles and provide for the logic of managing the socioeconomic development of the state.

The principles of public administration are understood as guiding rules, basic provisions, norms of behavior that reflect the most common stable features of laws and regularities of management, which must be observed in management activities (Maystro, 2013).

\section{Results and discussion}

\subsection{The context of world transformations of the state economic policy of the states in the conditions of COVID-19 world crisis}

The coronavirus outbreak has been a major challenge and shock to the world economy. Initially, China and, later, the world have experienced a decline in GDP, a sharp decline in the tourism business and financial problems.

The COVID-19 crisis has led to a situation where the economies of the states are suffering significant losses and another attempt is likely to "flood" the crisis with money: the European states will simply soften the monetary policy of central banks as much as possible. However, the crisis has hit a significant number of industries, including tourism, logistics, and the hotel business, and these areas will have significant problems. The crisis has been felt by world markets: oil prices have collapsed, as well as the stock markets.

Lebanon declared default on March 7, the first time in the state's history since independence in 1943. Estonia has also announced the onset of an economic crisis, with no such sharp drop since 2008. At the end of February, even the US indices have shown the largest decline since the 2008 financial crisis (Radchuk, 2020).

It is still difficult to estimate what the recession in the world economy will look like. It all depends on the duration of the crisis caused by the coronavirus, and this issue is multifaceted, as it concerns not only medicine, this issue is becoming geopolitical and geoeconomic in nature. Based on official public data, we can make a rather pessimistic forecast - the decline will be measured in double digits. However, it is likely that the indicators of economic development by the end of the year will be better than the results of the first half of the year.

This is a very specific crisis, which is different from all previous ones, and the classic measures to stimulate economic, political and public administration need to be adjusted. The basic forecast of economic world development assumes a sharp growth of the economy after a short recession after quarantine.

The financial capabilities of the EU states vary considerably. Therefore, only the finance ministers of these states know the answer to this question. Some of these states have already faced an excessive burden on the budget, while others have a fairly comfortable financial position. This means that the states must pursue counter-cyclical policies, that is, when their economies grow, seek to reduce budget deficits or even ensure their surpluses.

The answer to the question of what kind of crisis response policy they can afford, depends on the fiscal policy of the states before the crisis.

In economically developed states, where emergency measures have been introduced, governments and central banks issue trillions of dollars in government spending, social support of citizens, and interestfree business loans to limit the economic damage of quarantine. At the same time, in Latin America and Southeast Asia, where large families of several generations are housed in dense slums in multi-million cities, complete quarantine is often impossible. People who earn a living by working in temporary employment and low-paid jobs run the risk of losing their livelihoods and starving themselves if they stay at home. Communities that have already suffered from appalling living conditions, exploitation, inequality and environmental problems now face the triple threat of a coronavirus epidemic, economic crisis and natural disasters caused by climate change. 
For Asia, Africa and Latin America, this has resulted in an unprecedented health emergency and a deep economic crisis. The same effects are observed in wealthy states, but in poor states, where billions of people are on the brink of survival, even in the best of times, the dangers are mounting.

At the same time, there is a sharp decline in international investment in emerging markets and the withdrawal of capital from them. In 2019, a group of two dozen of developing states, including China, India, South Africa and Brazil, had a net investment inflow of 79 billion USD. In the last two months of 2020, more than 70 billion USD was withdrawn from these states. As a result, some states may fall into insolvency and default.

States dependent on the export of natural resources and raw materials, faced with the deadly danger of the COVID-19 epidemic and its consequences for the national economy, are forced to sell oil and other natural resources for nothing due to the global recession and suffer the greatest human and economic losses.

Combined with the negative effects of climate change, the socio-economic consequences for them can be dire and devastating. At the same time, capital accumulation centers can strengthen their positions and use the pandemic to get rich, gain even more power and unlimited access to the natural resources of the most affected states. Thus, the current crisis breaks the mask of decency and humaneness from the neocolonial system, showing its predatory murderous nature.

More than 150 states have set up anti-crisis headquarters and are taking anti-crisis measures (Kusa, 2020; Savitsky, 2020).

In connection with the coronavirus, the Trump administration proposed to reduce to $0 \%$ their payroll tax (contributions for social insurance and medicine, $6.2 \%+1.45 \%$ for employees and the same for employers, a total of $15.3 \%$ ).

Denmark will give a delay to VAT payers because of the coronavirus to mitigate the shock.

Australia intends to adopt a set of measures aimed at saving businesses from the after-effects of the coronavirus, in the form of tax incentives for investment, support for small and medium-sized businesses and benefits for retirees.

China is introducing tax breaks to protect its economy from the coronavirus.

The United Kingdom is planning tax breaks for vulnerable people and cheap loans for small businesses, and is even considering reducing VAT as a response to the coronavirus.

Italy will introduce tax breaks for businesses to help to overcome the effects of the epidemic.

Almost 150 states have identified a scenario for the development of state economic policy as a policy of saving the local economy and supporting small and medium-sized businesses while preserving jobs.

\subsection{Determining the state economic policy of Ukraine taking into account the factors of the COVID-19-20 crisis}

The general situation in the economy, despite the persistence of a number of significant problems and risks, indicates the gradual formation of a qualitative basis for further economic development in the new economic realities.

Can we try to predict how large-scale the global economic crisis will be and how it will hit Ukraine? The Ukrainian business suffers great losses.

The European Business Association has conducted a rapid survey among small and microbusiness, which is the basis of a market economy and forms the middle class. It showed that $18 \%$ of respondents are considering closing a business, $78 \%$ report losses of up to $75 \%$ of income, and only $4 \%$ report an increase in profits.

Labor market. According to the job search service Work.ua, since March 17, the number of vacancies has more than halved: on March 17, there were 38171 vacancies, and on April 21, 2020, their number decreased to 16683 vacancies.

In the IT industry, which exported 4.2 billion USD in computer services last year, the number of open vacancies from March 16 to April 20 decreased from 7326 to 4919 (Radchuk, 2020).

Business registration. Registration of new companies and individual entrepreneurs has experienced triple reduce during the quarantine period. If before the quarantine more than 5 thousand individual entrepreneurs were registered every week, then, according to the data on April 19, the number of registrations during the week decreased to 1.5 thousand (Voloshin, 2020).

From March 12 to April 15, 2020, YouControl has researched the dynamics of business opening and closing and found that there have been industries with the active growth. In particular, these are: production of pharmaceuticals $(+600 \%)$; production of cosmetics $(+100 \%)$; extraction of raw materials for the chemical industry $(+100 \%)(+100 \%)$ (Vinichuk, 2020).

The turnover of catering establishments has decreased by $73 \%$ since the beginning of March 2020, according to data from the company for automation of restaurants Poster, which serves 12 thousand establishments. Now the only way for restaurants to survive is working online.

Quarantine has dramatically changed the way businesses interact with customers: in self-isolation, consumers have begun to shop online en masse, where they prefer essential products. This has forced the business to reorient in a hurry, such large retailers as Silpo and Roshen confectionery corporation have gone online. In the first place, large online stores and online platforms have benefited from this. 
According to the Retailers portal, in March, the attendance of those services, the goods and services of which became in demand in the conditions of quarantine and self-isolation, sharply increased: in the service of products ordering Zakaz.ua the attendance increased by $73.7 \%$, in the pharmacy marketplace Liki24 - by $73 \%$, and in Tabletki.ua - by $32 \%$ (Vinichuk, 2020).

The analysts of Pro-Consulting predica that, according to the results of 2020, the food delivery market may grow to 50 billion UAH (from 20 billion UAH in 2019) (Voloshin, 2020).

In fact, Ukraine, in its current state, does not have the worst economic indicators than in 2008-2009 and in 2013-2014. The National Bank is still in control of the situation on the domestic financial market, we do not have a high level of inflation, economy with not too high debt ratio and opportunities for further GDP growth. However, the key risks remain the same as in previous years: a weak economy, dependent on the situation in foreign markets, lack of significant investment and strong development of small and medium-sized businesses, significant credit obligations, etc.

According to a study by the Ukrainian Institute for the Future, the consequences of the economic crisis for Ukraine are presented in Table 1 (Radchuk, 2020).

The most likely scenario in the event of a sharp decline in the world economy for the Ukrainian realities is default and a complete restructuring of the financial and industrial sectors. However, we should not forget about a significant local problem - Russia's military aggression and the possibility of new military operations in eastern Ukraine.

Currently, the best recipe for countering the crisis is to implement reforms and implement commitments made in cooperation with the IMF, also attracting investors and finding new markets.

The forecast of the state economic policy for 20202022 is formed on the basis of proposals of economists, political scientists and public administration specialists.

Given the global practice of making a forecast in the budget, which is the least risky, the baseline scenario assumes not the maximum possible, but a moderate response of the economy to the implemented reforms. Also, for a number of reforms, for which no consensus has been reached in society today, primarily land and tax reform, in this scenario, we proceed from the formation of conditions for the functioning of the economy on the principle of "status quo".

It is necessary to create an anti-crisis headquarters based on the type of developed states, which will be able to coordinate actions in the state (Amelin, 2020):

1. First and foremost, to create an anti-crisis plan and anti-crisis program of economic action of the state for 2020-2021.

2. To stabilize the macroeconomic situation as follows:

2.1. To carry out a moderate controlled devaluation to improve the economy and stimulate exports.

2.2. To balance and, if necessary, sequester budget expenditures.

2.3. To identify the main inflation targets and take measures to curb inflation expectations.

3. To develop and implement programs to support business and entrepreneurs, especially small businesses and the self-employed, as the basis of our economy.

3.1. To encourage the retention and creation of new jobs.

3.2. To neutralize the panic among the population (to develop measures to provide medical care and food during the quarantine period, to ensure the stabilization of the exchange rate in the cash market). To ensure competent communication between different levels of business, government and the public.

3.4. To encourage the consumption essential and permanent products in sufficient quantities, including through consumer lending (at a rate of $0 \%$ per annum) and job creation.

Table 1

Potential losses of Ukraine during the COVID 2020-2021 crisis

\begin{tabular}{|l|l|}
\hline \multicolumn{1}{|c|}{ The name of the current factor } & \multicolumn{1}{c|}{ Forecast results } \\
\hline Export & Fall by 16\% in 2 years (-10 billion USD) \\
\hline Trade balance deficit & Growth to -13 billion USD \\
\hline Current account balance & -7 billion USD \\
\hline The official exchange rate of USD / UAH & Reduction to 35-37 UAH / USD \\
\hline Credit rating of Ukraine & Decrease to pre-default \\
\hline The cost of borrowing in foreign markets & Growth from 5 to 8\% (in foreign currency) \\
\hline Volume of the NBU reserves & Reduction up to 10-15 billion USD in imports \\
\hline Real hryvnia GDP & Falling by 8-10\% per year \\
\hline Dollar GDP & Reduction to 20-30 billion USD \\
\hline Falling wages in dollars & $-15-20 \%$ \\
\hline Job loss & Up to 500 thousand people \\
\hline Return of migrant workers & Up to 3 million people (low-skilled staff) \\
\hline
\end{tabular}

Source: compiled on the basis of (Radchuk, 2020; Vinichuk, 2020; Voloshin, 2020) 
3.5. To create and implement a program to support exporters (intensify the work of the Export Credit Agency, create a network of trade missions within the export strategy, tax preferences for exporters of hightech products, especially agricultural products).

3.6. To create and implement a comprehensive program to stimulate import substitution, localize the production of imported products today, and support domestic producers.

3.7. To carry out tax reform and launch Exit Capital Tax (tax on distributed profit) as a factor in stimulating business activity and accelerating the modernization of the economy (after the active phase of the crisis, but to prepare the base in advance).

3.8. To restore the possibility of functioning of special economic zones, industrial parks as a factor in attracting investment in new sectors of the economy and creating new jobs.

3.9. To create and implement an anti-crisis program to support the Ukrainian producers and industry.

4. To establish the Kyiv International Financial Center with the participation of international financial institutions and work under the British law in order to attract investment and mitigate the risks of the Ukrainian jurisdiction ( 2 years for project preparation, start - after the crisis).

5. To prepare and launch infrastructure projects in the format of PPP (public-private partnership) (ports, airports), including on the state guarantees. Infrastructure projects in crisis are an important support to the economy, stimulating domestic consumption and job creation.

6. To intensify and complete the implementation of the digital strategy of Ukraine as a factor that can increase the productivity of the economy.

Among the risks of the forecast, which may worsen the situation, there should be noted:

- strengthening of the hybrid threats to Ukraine's national security, including active military confrontation in the east of the state, which could have extremely unpredictable consequences both in the short term and in terms of the scale of the destruction of development potential;

- aggravation of the socio-political situation in the state, which, against the background of reduced efficiency of international cooperation, will cause a decline in production activity, will form threatening devaluation trends in the foreign exchange market (increasing exchange rate volatility) and inflation in the state with growing negative expectations and confrontations;

- the risk of implementing populist measures in the social direction, especially during periods of expected increase in political activity;

- more than the predicted increase in world food prices and accelerated growth in the cost of energy resources; - lower yields of individual crop products than expected;
- the risk of non-continuation of cooperation with the IMF or new conditions of cooperation on less favorable terms for Ukraine;

- tougher conditions in global financial markets;

- the risk of increasing the level of labor migration and the strengthening of the refugee factor, which, combined with the growing poverty of Ukraine and incomplete transformation processes in the labor market, including the aggravation of the situation in rural areas, will reduce human resources in the state.

\section{Conclusions}

Consequently, the state economic policy is a strategy of purposeful influence on economic processes at the macro and micro levels, creation of conditions and improvement of directions of development of economy according to a certain social system. In addition, the essence of state economic policy should not be reduced only to a set of methods and levers of managerial influence on economic processes. The managerial influence of the state includes not only regulation, but also organization, planning and control. The basis of state economic policy should be to determine the purpose of the economic system, the specific functions of each of its elements to achieve this goal and their interaction with other elements of the system, which will be the subject of further research.

The general situation in the economy, despite the persistence of a number of significant problems and risks, indicates the gradual formation of a qualitative basis for further economic development in the new economic realities.

The COVID-19 crisis has led to a situation where the economies of the states are suffering significant losses and another attempt is likely to "flood" the crisis with money: the European states will simply soften the monetary policy of central banks as much as possible, and the situation might be improved in 2-3 quarters. If we talk about oil prices, we cannot say about a significant reduction in high demand for it - the price also stabilizes in 2-3 quarters.

Currently, the best recipe for countering the crisis is to implement reforms and implement commitments made in cooperation with the IMF, also attracting investors and finding new markets.

We define that there are a number of risks which realization will influence the realization of forecast estimations. Among the main point, the folowing should be noted:

- uncertainty of the political situation, with a constant threat of escalation of hostilities;

- continuing the trend of increasing labor migration with a probable high deficit of human resources in Ukraine;

- suspension of cooperation with international financial organizations. 


\section{References:}

Adamovska, A. (2017). Mechanism of state regulation of economy and choice of direction of economic policy in modern conditions of management. Public Administration: Improvement and Development, no. 4. Retrieved from: http://www.dy.nayka.com.ua/ ?op $=1 \& z=1063$

Amelin, A. (2020). Economic crisis - 2020: What are the consequences for Ukraine and how to deal with it. Retrieved from: https://zik.ua/blogs/ekonomichna_kryza_2020_yaki_naslidky_dlia_ukrainy_ta_iak_z_tsym_ vporatys_962014

Arkhypenko, Y. (2019). Foreign experience in the formation and implementation of regional economic policy. Public Administration and Local Self-Government, no. 2(41). Retrieved from: http://www.dridu.dp.ua/ vidavnictvo/2019/2019_02(41)/6.pdf

Didkivska, L. I., \& Holovko, L. S. (2000). State regulation of the economy: textbook. tool. Kiev: Knowledge Press. Emerson, M., \& Kovziridze, T. (eds) (2018). Deepening Relations between Georgia and the EU - Why, what and how?, CEPS and Rowman \& Littlefield International, 2 nd edition.

Global Competitiveness Report 2018, World Economic Forum. Retrieved from: https://www.weforum.org/ focus/davos-2018

Kusa, I. (2020). The crisis in the United States, the Middle East on fire, controversial Europe: what the world will be like in 2020. Retrieved from: https://dif.org.ua/article/kriza-v-ssha-blizkiy-skhid-u-vogni-superechlivaevropa-yakim-bude-svit-u-2020-mu

Luzin, Pavel (2015). “The Caucasus: Imperial Realpolitik or Historical Retreat”, Intersections, 7 December.

Maclean, Rory (2013). "Heroic Adventures in Transnistria”, New Eastern Europe, No. 4 (IX), p. 158.

Makarychev, Andrey and Strukov, Vlad (2017). “(In)complete Europe vis-à-vis (in)complete Russia”, PONARSEurasia website, 5 June.

Martunyuk, V. (2017). “Eastern Partnership summit: Compromise for the sake of continuation”, Ukrainian Prism, Foreign Policy Council, 27 November.

Martunyuk, O., Vitvitskaya, O., \& Lagodiienko, V. (2019). Formation of an innovative concept of management on the basis of reconstruction of genetic algorithm of management technology. Periodicals of Engineering and Natural Sciences, vol. 7, no. 2, pp. 487-499. doi: 10.21533/pen.v7i2

Matsaberidze, D. (2015). "Russia vs. EU/US through Georgia and Ukraine”, Connections, The Quarterly Journal, spring, p. 86.

Maystro, S. (2013). Theoretical and methodological principles of the implementation of state economic policy. Public administration theory and practice, no. 2(41), pp. 1-7. Retrieved from: http://www.kbuapa.kharkov.ua/ e-book/tpdu/2013-2/doc/2/02.pdf

Kulysh, L. (2019). Competition policy in the system of instruments of state regulation of the economy. Economy and the state, no. 1. Retrieved from: http://www.economy.in.ua/pdf/1_2019/23.pdf

Radchuk, O. (2020). The New World Economic Crisis: Will Ukraine Meet the Challenges? Retrieved from: https://www.slovoidilo.ua/2020/03/05/kolonka/aleksandr-radchuk/ekonomika/nova-svitova-ekonomichnakryza-chy-vporayetsya-ukrayina-vyklykamy

Savitsky, O. (2020). The crisis of 2020: the end of the colonial world and the beginning of a new one. Retrieved from: https://ua.boell.org/uk/2020/04/13/kriza-2020-roku-kinec-kolonialnogo-svitu-ta-pochatok-novogo

Serzhanov, V., \& Kostovyat, A. (2018). Strategic management in the system of socio-economic development of Ukraine. International conference «Regional sustainable development - through competitiveness, innovation and human capital».

Soloviov, V. (2017). "For Moldova's journalists, surveillance is the new norm", Open Democracy, 7 April.

Ukraine on the Economic Freedom Level (2018). Economic Discussion Club Public Association. Public Administration: Improvement and Development, no. 4. Retrieved from: http://edclub.com.ua/analityka/ukrayina-za-rivnemekonomichnoyi-svobody-2018

Umantsiv, Yu. M. (2015). Mekhanizm ekonomichnoyi polityky : navch. posib.: The Mechanism of Economic Policy: A Study. guide: Retrieved from: http://pidruchniki.ws/15970122/ekonomika/metodologichni_zasadi_ formuvannya_realizatsiyi_ekonomichnoyi_politiki\#159

Vinichuk, Y. (2020). What happens to the Ukrainian quarantine business Retrieved from: https://biz.censor.net.ua/ resonance/3190487/scho_vdbuvatsya_z_ukranskim_bznesom_na_karantin

Voloshin, M. (2020). Global Crisis $20 \overline{2} 0$ and Coronavirus: What will happen to the economy? Retrieved from: https://vgolos.com.ua/news/svitova-kryza-2020-i-koronavirus-shho-bude-z-ekonomikoyu_1191896.html 